\title{
INDEPENDENT CONFIRMATORY SURVEY SUMMARY AND RESULTS FOR THE HEMATITE DECOMMISSIONING PROJECT FESTUS, MISSOURI
}

Erika N. Bailey
and
Mark G. Jadick

Prepared for the

U.S. Nuclear Regulatory Commission
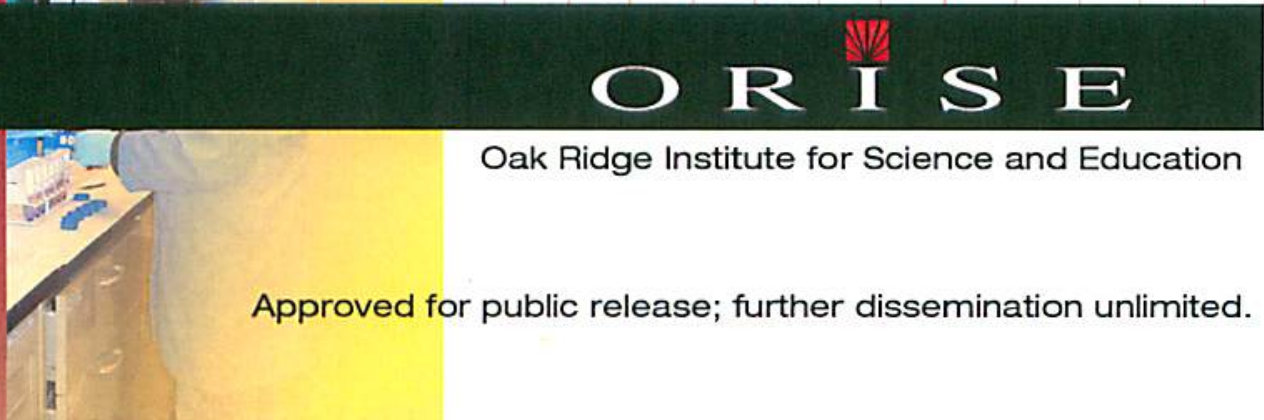

Oak Ridge Institute for Science and Education

Approved for public release; further dissemination unlimited. 
The Oak Ridge Institute for Science and Education (ORISE) is a U.S. Department of Energy facility focusing on scientific initiatives to research health risks from occupational hazards, assess environmental cleanup, respond to radiation medical emergencies, support national security and emergency preparedness, and educate the next generation of scientists. ORISE is managed by Oak Ridge Associated Universities. Established in 1946, ORAU is a consortium of 99 colleges and universities.

\section{NOTICES}

The opinions expressed herein do not necessarily reflect the opinions of the sponsoring institutions of Oak Ridge Associated Universities.

This report was prepared as an account of work sponsored by the United States Government. Neither the United States Government nor the U.S. Department of Energy, nor any of their employees, makes any wartanty, expressed or implied, or assumes any legal liability or tesponsibility for the accuracy, completeness, or usefulness of any information, apparatus, product, or process disclosed or represents that its use would not infringe on privately owned rights. Reference herein to any specific commercial product, process, or service by trade name, mark, manufacturer, or otherwise, does not necessarily constitute or imply its endorsement or recommendation, or favor by the U.S. Government or any agency thereof. The views and opinions of authors expressed herein do not necessarily state or reflect those of the U.S. Government or any agency thereof. 


\section{INDEPENDENT CONFIRMATORY SURVEY SUMMARY \\ AND RESULTS FOR THE \\ HEMATITE DECOMMISSIONING PROJECT \\ FESTUS, MISSOURI}

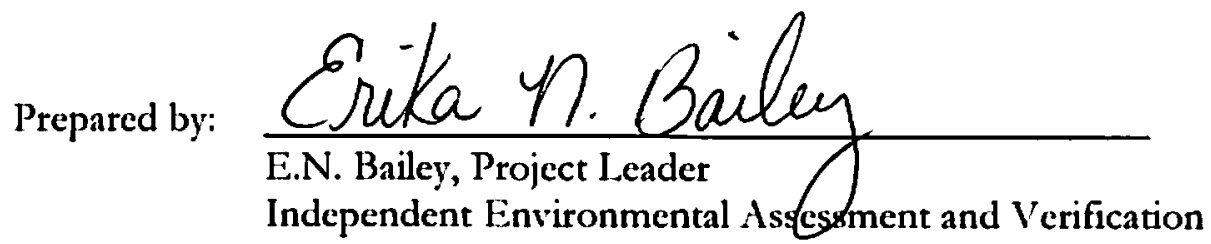

Date: $3 / 18 / 09$

Reviewed by:

Independent Elfironmental Assessment and Verification

Reviewed by: $\frac{\text { R.h. Condua Date: } 3 / 18 / 09}{\text { R. D. Condra Laboratory Manager }}$

R. D. Condra, Laboratory Manager

Independent Environmental Assessment and Verification

Reviewed by: $\frac{\text { Cum } 7 \text { Papee }}{\text { A. T. Payne, Quality Manager }} \quad$ Date: $3 / 18 / 09$

Independent Environmental Assessment and Verification

Reviewed by: $\frac{\text { Sonah Joberts, Associate Program Director }}{\text { Independent Environmental Assessment and Verification }}$ Date: $3 / 18 / 09$ 


\title{
INDEPENDENT CONFIRMATORY SURVEY SUMMARY \\ AND RESULTS FOR THE \\ HEMATITE DECOMMISSIONING PROJECT \\ FESTUS, MISSOURI
}

\author{
Prepared by \\ Erika N. Bailey and Mark G. Jadick \\ Oak Ridge Institute for Science and Education \\ Oak Ridge, Tennessee 37831-0017 \\ Prepared for the \\ U.S. Nuclear Regulatory Commission
}

FINAL REPORT

March 2009

This report is based on work performed under an Interagency Agreement (NRC Fin. No. J-5403) between the U.S. Nuclear Regulatory Commission and the U.S. Department of Energy. The Oak Ridge Institute for Science and Education performs complementary work under contract number DE-AC05-06OR23100 with the U.S. Department of Energy. 


\title{
ACKNOWLEDGMENTS
}

The authors would like to acknowledge the significant contributions of the following staff members:

FIELD STAFF

T. D. Herrera

\section{LABORATORY STAFF}

R. D. Condra

J. S. Cox

W. P. Ivey

W. F. Smith

\section{CLERICAL STAFF}

R. M. Fink

K. M. Moore

A. Ramsey

\section{ILLUSTRATOR}

\author{
J. A. Viars
}




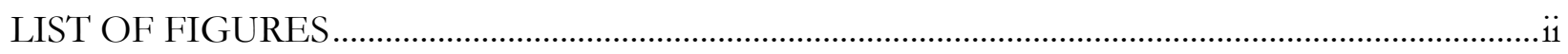

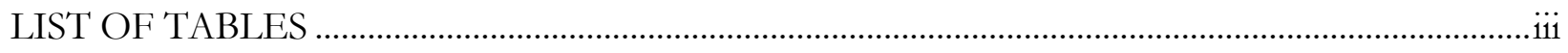

ABBREVIATIONS AND ACRONYMS .............................................................................................

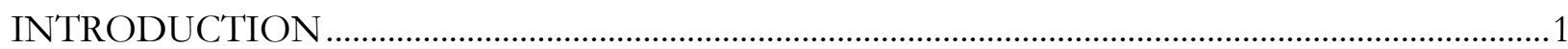

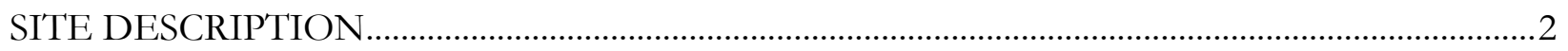

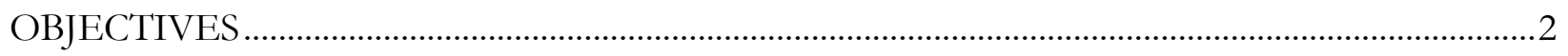

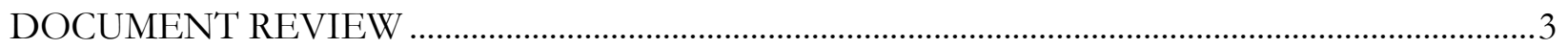

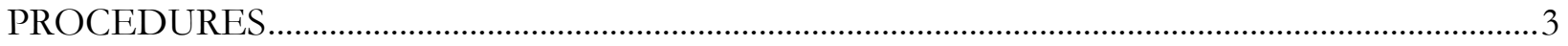

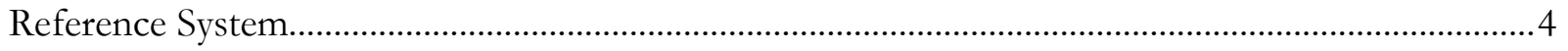

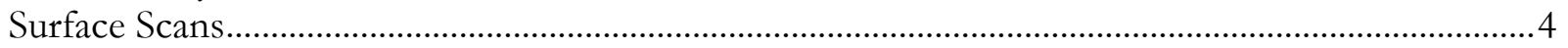

Surface Activity Measurements .....................................................................................................

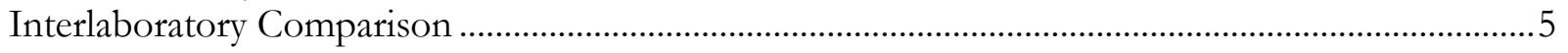

SAMPLE ANALYSIS AND DATA INTERPRETATION ……………………………………....

APPLICABLE SITE GUIDELINES ......................................................................................

FINDINGS AND RESULTS ………………………………………………………….6

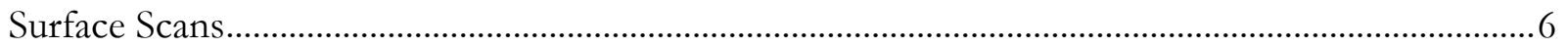

Surface Activity Measurements .......................................................................................................6

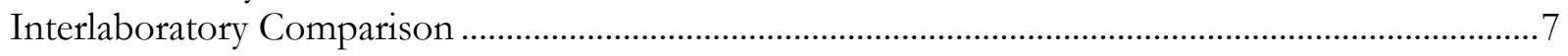

COMPARISON OF RESULTS WITH GUIDELINES.....................................................................

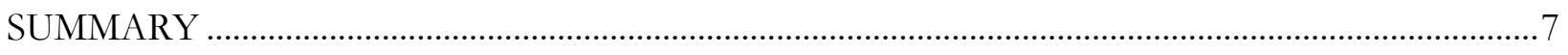

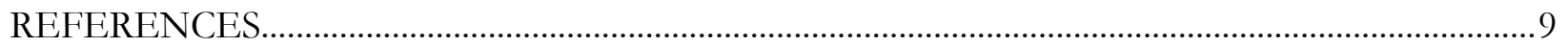

APPENDICES:

Appendix A: Figures

Appendix B: Tables

Appendix C: Major Instrumentation

Appendix D: Survey and Analytical Procedures 


\section{LIST OF FIGURES}

PAGE

Figure 1: Plot Plan of the Hematite Decommissioning Project ........................................................ A-1

Figure 2: Building 110 - Gamma Scan Results and Sample Location.............................................. A-2

Figure 3: Building 230 - Gamma Scan Results .............................................................................. A-3

Figure 4: Building 230 HEPA Room - Gamma Scan Results ........................................................ A-4

Figure 5: Proposed Rail Spur Area - Gamma Scan Results............................................................ A-5 


\section{LIST OF TABLES}

$\underline{\text { PAGE }}$

Table 1: Concentrations and Comparison of Results for Selected Gamma Emitting Radionuclides in Soil Samples................................................................................................

Table 2: Concentrations of Uranium Isotopes in Soil Samples ...............................................................7

Table 3: Concentrations Of Technetium-99 in Soil Samples .................................................................8 


\section{ABBREVIATIONS AND ACRONYMS}

\begin{tabular}{|c|c|}
\hline $\begin{array}{l}b_{i} \\
d^{\prime}\end{array}$ & $\begin{array}{l}\text { number of background counts in the interval } \\
\text { index of sensitivity }\end{array}$ \\
\hline$\varepsilon_{\mathrm{i}}$ & instrument efficiency \\
\hline$\varepsilon_{\mathrm{s}}$ & surface efficiency \\
\hline$\varepsilon_{\text {total }}$ & total efficiency \\
\hline Am-241 & americium-241 \\
\hline $\mathrm{BKG}$ & background \\
\hline $\mathrm{cm}$ & centimeter \\
\hline $\mathrm{cm}^{2}$ & square centimeter \\
\hline cpm & counts per minute \\
\hline DCGL & derived concentration guideline level \\
\hline $\mathrm{DCGL}_{\mathrm{W}}$ & $\begin{array}{l}\text { DCGL for average concentrations over a wide area, used with } \\
\text { statistical tests }\end{array}$ \\
\hline $\mathrm{dpm} / 100 \mathrm{~cm}^{2}$ & disintegrations per minute per 100 square centimeters \\
\hline FSS & final status survey \\
\hline GPS & Global Position System \\
\hline HDP & Hematite Decommissioning Project \\
\hline HEPA & high-efficiency particulate air \\
\hline IEAV & $\begin{array}{l}\text { Independent Environmental Assessment and Verification } \\
\text { Program }\end{array}$ \\
\hline ITP & Intercomparison Testing Program \\
\hline MAPEP & Mixed Analyte Performance Evaluation Program \\
\hline MARSSIM & Multi-Agency Radiation Survey and Site Investigation Manual \\
\hline MDC & minimum detectable concentration \\
\hline MDCR & minimum detectable count rate \\
\hline $\mathrm{MeV}$ & million electron volts \\
\hline $\mathrm{mg}$ & milligram \\
\hline $\min$ & minute \\
\hline $\mathrm{mm}$ & millimeter \\
\hline $\mathrm{mrem} / \mathrm{yr}$ & millirem per year \\
\hline $\mathrm{NaI}$ & sodium iodide \\
\hline NIST & National Institute of Standards and Technology \\
\hline $\mathrm{Np}-237$ & neptunium-237 \\
\hline NRC & U.S. Nuclear Regulatory Commission \\
\hline NRIP & NIST Radiochemistry Intercomparison Program \\
\hline ORAU & Oak Ridge Associated Universities \\
\hline ORISE & Oak Ridge Institute for Science and Education \\
\hline $\mathrm{pCi}$ & picocuries \\
\hline $\mathrm{Pu}-239 / 240$ & plutonium-239/240 \\
\hline s & second \\
\hline Tc-99 & technitium-99 \\
\hline Th-232 & thorium-232 \\
\hline UF6 & uranium hexafluoride \\
\hline $\mathrm{U}-234$ & uranium-234 \\
\hline $\mathrm{U}-235$ & uranium-235 \\
\hline $\mathrm{U}-238$ & uranium-238 \\
\hline WEC & Westinghouse Electric Company \\
\hline
\end{tabular}




\section{INDEPENDENT CONFIRMATORY SURVEY SUMMARY AND RESULTS FOR THE HEMATITE DECOMMISSIONING PROJECT FESTUS, MISSOURI}

\section{INTRODUCTION}

The Westinghouse Electric Company, LLC (WEC) former fuel cycle facility near Festus, Missouri operated from 1956 to 2001 manufacturing uranium from natural and enriched uranium for use as nuclear fuel. The site ceased operational activities in September 2001 and is now proposing to decommission the facility which is now known as the Hematite Decommissioning Project (HDP). From its inception in 1956 through 1974, the facility was used primarily in support of government contracts that required production of highly enriched uranium products. From 1974 through the plant closure in 2001, the focus changed from government contracts to commercial fuel production. Specifically, operations included the conversion of uranium hexafluoride (UF6) gas of various uranium enrichments to uranium oxide, uranium carbide, uranium dioxide pellets, and uranium metal. Secondary operations included research and development and uranium scrap recovery processes. The facility's central land area and the site creek were impacted by the fuel fabrication activities. Currently within permitted license activities, WEC has performed equipment decontamination and dismantlement and has shipped various equipment and material off site. WEC is also proposing to install a rail spur to allow direct loading of rail cars for offsite waste shipments.

The U.S. Nuclear Regulatory Commission (NRC) is responsible for oversight of permitted license activities that are currently being conducted at the HDP. The NRC has opted to perform independent (third party) confirmatory activities of various site activities. The purpose of confirmatory activities is to verify that any remedial actions have been effective in meeting site-specific guidelines and that documentation accurately and adequately describes the radiological conditions at the site. Oak Ridge Institute for Science and Education (ORISE) was designated as the organization responsible for this task at HPD. Specifically, ORISE was tasked to confirm the current radiological status of the roofs of Buildings 110 and 230, the high-efficiency particulate air (HEPA) room of Building 230, and the land area impacted by the proposed rail spur, and to observe ongoing site soil characterization core boring activities. The following descriptions of the buildings were taken from the Hematite Decommissioning Plan (WEC 2005). 
Building 110 is the Pedestrian Entrance/Office Building. This building was built in 1970 and serves as the pedestrian entrance into the plant. The building currently has a security station at the entrance, several offices, a conference room, and a kitchen. No work with radioactive or chemical compounds is known to have occurred in this building and prior licensee surveys have shown no building surfaces that exhibit levels of radioactive contamination above the proposed levels for unrestricted use.

Building 230 is the Rod Loading Building. It was built in 1992 to receive finished pellets (i.e., standard, erbium, and gadolinium) which were then loaded into fuel rods and assemblies for shipment off site. No appreciable amounts of chemicals were used in this building and contact with fuel pellets was limited to two small areas. The building is currently being used as office space. The building surfaces have no known levels of radioactive contamination above the proposed levels for unrestricted use. During the period of mid-2003 to mid-2004, this building underwent radiological remediation in preparation for its current use as the Decommissioning Project office. A Multi-Agency Radiation Survey and Site Investigation Manual (MARSSIM) "final status survey" (FSS) was conducted by the project in order to remove radiological controls on the building. While extensive, these surveys were not intended to serve as justification for the final radiological status.

\section{SITE DESCRIPTION}

The Hematite facility is located in Jefferson County Missouri less than 4 miles west of the town of Festus, Missouri and 35 miles south of the city of St. Louis. The site is surrounded by forest and agricultural lands and low density residential housing. The entire site consists of approximately 228 acres; however, the impacted portion of the site, referred to as the central tract, only includes approximately 19 acres. The central tract of the site is bounded by State Road P to the north, the northeast site creek to the east, Union-Pacific railroad tracks to the south, and the site creek/pond to the west.

\section{OBJECTIVES}

The objectives of the confirmatory surveys were to provide independent contractor field data reviews and to generate independent radiological data for use by the NRC in evaluating the adequacy and accuracy of the licensee's procedures and survey results. 


\section{DOCUMENT REVIEW}

Prior to onsite activities, ORISE reviewed limited documentation including revision 2 of the Hematite Decommissioning Plan (WEC 2005). The NRC did not approve revision 2; however, ORISE primarily used it for historical site information. In addition, the site provided ORISE with the proposed site-specific derived concentration guideline levels (DCGLs); however, the DCGL derivation document was in draft form, had not undergone internal WEC review and comment, nor had it been approved by the NRC (WEC 2008). Therefore, the proposed DCGLs are currently only considered as preliminary, working values. While on site, the site contact provided ORISE with survey and sample data for the subject areas from previous characterization activities. All documents and data were reviewed for adequacy and appropriateness taking into account the MARSSIM guidance (NRC 2000).

\section{PROCEDURES}

A survey team from ORISE visited the HDP from June 24 through 26, 2008 to perform visual inspections and measurement and sampling activities. Confirmatory survey activities were conducted in accordance with a site-specific survey plan, the ORISE/IEAV Survey Procedures Manual and the Quality Program Manual (ORISE 2008a, 2008b and ORAU 2007). Figure 1 shows an aerial photo of the areas involved in the confirmatory activities as discussed below.

WEC has subdivided the site into survey units; survey units are classified based on contamination potential, as either Class 1, 2, or 3 in accordance with MARSSIM (NRC 2000). A description of each is as follows:

Class 1: $\quad$ Buildings or land areas that have a significant potential for radioactive contamination (based on site operating history) or known contamination (based on previous radiological surveys) that exceeds the proposed derived concentration guideline value $\left(\mathrm{DCGL}_{\mathrm{W}}\right)$.

Class 2: $\quad$ Buildings or land areas, often contiguous to Class 1 areas that have a potential for radioactive contamination but at levels less than the proposed DCGL $\mathrm{L}_{\mathrm{W}}$. 
Class 3: $\quad$ Remaining impacted buildings and land areas that are not expected to contain residual contamination, or are expected to contain levels of residual contamination at a small fraction of the proposed $\mathrm{DCGL}_{\mathrm{W}}$.

The ORISE survey activities were conducted to confirm the current radiological status of the roofs of Buildings 110 and 230, including the roof of the HEPA room of Building 230 (all are Class 3s), the land area impacted by the proposed rail spur, and to observe ongoing site characterization core boring activities.

\section{REFERENCE SYSTEM}

All scans were performed outdoors; therefore, all gamma scan data were referenced to global positioning systems (GPS) coordinates. Measurement/sampling locations were documented on a survey map provided by the licensee.

\section{SURFACE SCANS}

Gamma and alpha plus beta surface scans of the building roofs were performed as well as gamma surface scans over the proposed rail spur area. Medium to high density scans were performed over these areas. On the roofs, particular attention was given to surfaces where material may have accumulated such as in cracks and joints, ledges, and other horizontal surfaces. ORISE was asked to stay at least 15 feet from the edges of the roofs if there was not a fall protection barrier in place. Scans were performed using sodium iodide $(\mathrm{NaI})$ scintillation detectors for direct gamma radiation and gas proportional detectors for direct alpha plus beta radiation. Both types of detectors were coupled to ratemeter-scalers with audible indicators. The NaI detectors were also coupled to GPS systems that enabled real-time gamma count rate and position data capture.

\section{SuRfaCE ACTIVITy MEASUREMENTS}

Based on the radiation levels observed on the roofs during surface scans (background levels), ORISE opted not to perform extensive direct measurements. One direct measurement was performed on the roof of Building 110 (in a gutter) from the location exhibiting the highest alpha plus beta radiation level identified by ORISE. The direct measurement was made using a gas proportional detector coupled to a ratemeter-scaler. One smear sample was also collected at this 
location to determine the removable gross alpha and gross beta activity levels. The measurement location is illustrated on Figure 2.

\section{INTERLABORATORY COMPARISON}

At the request of NRC Region III, ORISE was tasked with conducting an interlaboratory comparison to evaluate the quality of the licensee's radioanalytical data. The NRC selected 26 soil samples, collected by the licensee, for interlaboratory comparison analyses. These samples were collected within the boundary of the proposed rail spur area. For the gamma spectroscopy comparative analysis, ORISE requested and received the same sample analyzed by the licensee's contract laboratory, Test America. In order to perform liquid scintillation analyses for technitium-99 (Tc-99), ORISE requested an additional unprocessed (wet) portion be collected and sent.

\section{SAMPLE ANALYSIS AND DATA INTERPRETATION}

The one smear sample collected on site was returned to the ORISE laboratory in Oak Ridge, Tennessee for analysis and interpretation. The soil samples were shipped to the ORISE laboratory from Test America. Sample analyses were performed in accordance with the ORISE Laboratory Procedures Manual (ORISE 2008c). The smear sample collected for the quantification of gross alpha/beta activity was analyzed using a low-background proportional counter. The smear sample and direct measurement results are reported in units of disintegrations per minute per one-hundred square centimeters $\left(\mathrm{dpm} / 100 \mathrm{~cm}^{2}\right)$. Soil samples were analyzed by gamma spectroscopy for the main gamma-emitting contaminants of concern: thorium-228 (Th-228), thorium-232 (Th-232), uranium-235 (U-235), and uranium-238 (U-238). Wet chemistry extraction followed by liquid scintillation analysis was used to quantify Tc-99. The soil samples were also analyzed for U-233/ U-234, U-235, and U-238 via alpha spectroscopy. Soil sample results were reported in units of picocuries per gram $(\mathrm{pCi} / \mathrm{g})$.

\section{APPLICABLE SITE GUIDELINES}

Based on past site investigations, the primary contaminants of concern at the HDP are Tc-99, Th-232, U-234, U-235, and U-238. Secondary radiological contaminants include the transuranic radionuclides of americium-241 (Am-241), neptunium-237 (Np-237), and plutonium-239/240 (Pu-239/240) because they are likely to be present only in trace concentrations (WEC 2005). 
The proposed surface soil derived concentration guideline levels (DCGLs) for the site have not yet been approved by the NRC so they are not included at this time. However, the soil DCGL values will be used for FSS samples to determine compliance with the $25 \mathrm{mrem} / \mathrm{yr}$ criterion.

Likewise, the proposed DCGL values for building surfaces have not been approved. The DCGL values will be the surface activity levels in $\mathrm{dpm} / 100 \mathrm{~cm}^{2}$ that will be used to evaluate measurements to determine compliance with the $25 \mathrm{mrem} / \mathrm{yr}$ criterion.

The laboratory analyses and surface activity measurement data collected by ORISE are provided and can be compared to the site-specific DCGL values once they have been approved.

\section{FINDINGS AND RESULTS}

\section{SURFACE SCANS}

Surface scans of the roofs did not identify radiation levels greater than background levels, with the exception of generally elevated alpha plus beta radiation associated with the gutters. Although not confirmed via sampling during this survey, these elevated radiation levels are commonly found with gutters. Prior experience has determined the origin to be either radon progeny electrostatically bound to the metal or results from short-term build-up of beryllium-7 in sediments that collect in low points. The gamma scans of the proposed rail spur area did identify elevated gamma radiation levels; however, the identified areas of contamination were consistent with the licensee's findings. Refer to Figures 2 through 5 for the gamma scan results.

\section{SurfaCE ACTIVITy MEASUREMENTS}

One direct measurement was performed on the roof of Building 110 at the location exhibiting the highest alpha plus beta radiation level identified by ORISE (Figure 2). The surface activity value of $5,500 \mathrm{dpm} / 100 \mathrm{~cm}^{2}$ represents the gross surface activity level that has not been corrected for background contributions. Corrected for background the surface activity is $3,900 \mathrm{dpm} / 100 \mathrm{~cm}^{2}$ and is most likely the result of naturally occurring radiation. Removable activity at this location was $0 \mathrm{dpm} / 100 \mathrm{~cm}^{2}$ for gross alpha and $2 \mathrm{dpm} / 100 \mathrm{~cm}^{2}$ for gross beta. 


\section{INTERLABORATORY COMPARISON}

The WEC soil sample data were provided by the licensee in a report requested by the NRC (WEC 2008). Refer to Tables 1 through 3 for comparison data. With the exception of one sample_-ORISE sample number 1768S0011 — the WEC contract laboratory gamma spectroscopy analyses were consistent and in agreement with the ORISE analytical results. However, a large fraction of the alpha spectroscopy and the Tc-99 analyses were not in agreement within the expected statistical uncertainties. The most likely explanation for the Tc-99 differences is that ORISE analyzed an unprocessed (wet) portion of the sample (the recommended methodology for Tc-99 analysis). The WEC contract laboratory analyzed a dry portion of each sample for Tc-99. As Tc-99 is considered somewhat volatile, an unknown portion of the Tc-99 may have been released from the sample during the drying process performed at the WEC contract laboratory. Without knowing the exact extraction procedure used by the WEC contract laboratory, it is difficult for ORISE to address the differences in the alpha spectroscopy data.

\section{COMPARISON OF RESULTS WITH GUIDELINES}

The laboratory analyses and surface activity measurement data collected by ORISE is provided and can be compared to the site-specific DCGL values once they have been approved.

\section{SUMMARY}

At the request of the U.S. Nuclear Regulatory Commission, the Oak Ridge Institute for Science and Education conducted confirmatory surveys at the Hematite Decommissioning Project during the period of June 24 through 26, 2008. The survey activities included visual inspections and measurement and sampling activities.

The confirmatory surface scans of the roofs of Buildings 110 and 230, including the HEPA room of Building 230, did not identify radiation levels greater than background levels. The gamma scans of the proposed rail spur area did identify elevated radiation levels; however, the identified areas of contamination were consistent with the licensee's findings.

The one smear collected did not indicate removable activity. ORISE's radiological survey data confirm that the radiological conditions of the areas surveyed were commensurate with licensee's 
findings. Confirmatory survey activities validated the licensee's conclusions regarding each area's classification, and radiological status.

The interlaboratory comparison of soil samples resulted in significant differences in the soil sample data analyzed by alpha spectroscopy and the Tc-99 analyses. The differences in the Tc-99 analyses are most likely due to the difference in procedures used (analyzing dry samples verses wet). However, without knowing the exact alpha spectroscopy procedure used by the WEC laboratory it is difficult to address those differences. Therefore, ORISE requests additional information regarding the procedures used by the licensee's laboratory in order to further address the alpha spectroscopy differences. If it is determined that WEC laboratory procedures are not acceptable/approved analyses methods, the collection of additional samples may be warranted. 


\section{REFERENCES}

Oak Ridge Associated Universities (ORAU). Quality Program for the Independent Environmental Assessment and Verification Program. Oak Ridge, Tennessee; November 1, 2007.

Oak Ridge Institute for Science and Education (ORISE). Final Confirmatory Survey Plan for the Roof Surveys of Buildings 110 and 230; the Building 230 HEPA Room; Proposed Rail Spur; and Core Boring Activities, Hematite Decommissioning Project, Festus, Missouri 1768-PL-01-0.

Oak Ridge, Tennessee; June 24, 2008a.

Oak Ridge Institute for Science and Education. Survey Procedures Manual for the Independent Environmental Assessment and Verification Program. Oak Ridge, Tennessee; May 1, 2008b.

Oak Ridge Institute for Science and Education. Laboratory Procedures Manual for the

Environmental Survey and Site Assessment Program. Oak Ridge, Tennessee; September 10, 2008c.

U.S. Nuclear Regulatory Commission (NRC). Multi-Agency Radiation Survey and Site Investigation Manual (MARSSIM), NUREG-1575; Revision 1. Washington, DC; August 2000.

Westinghouse Electric Company (WEC). Hematite Decommissioning Plan. Document No. DO-04-004, Rev. 2. Hematite, MO; August 2005.

Westinghouse Electric Company. Re: Request for Radiochemistry Data and Figure Illustrating the Sampling Locations during NRC Inspection IR-070-00036/08-001. Document No. HEM-08-78. Hematite, MO; August 8, 2008. 
APPENDIX A

\section{FIGURES}




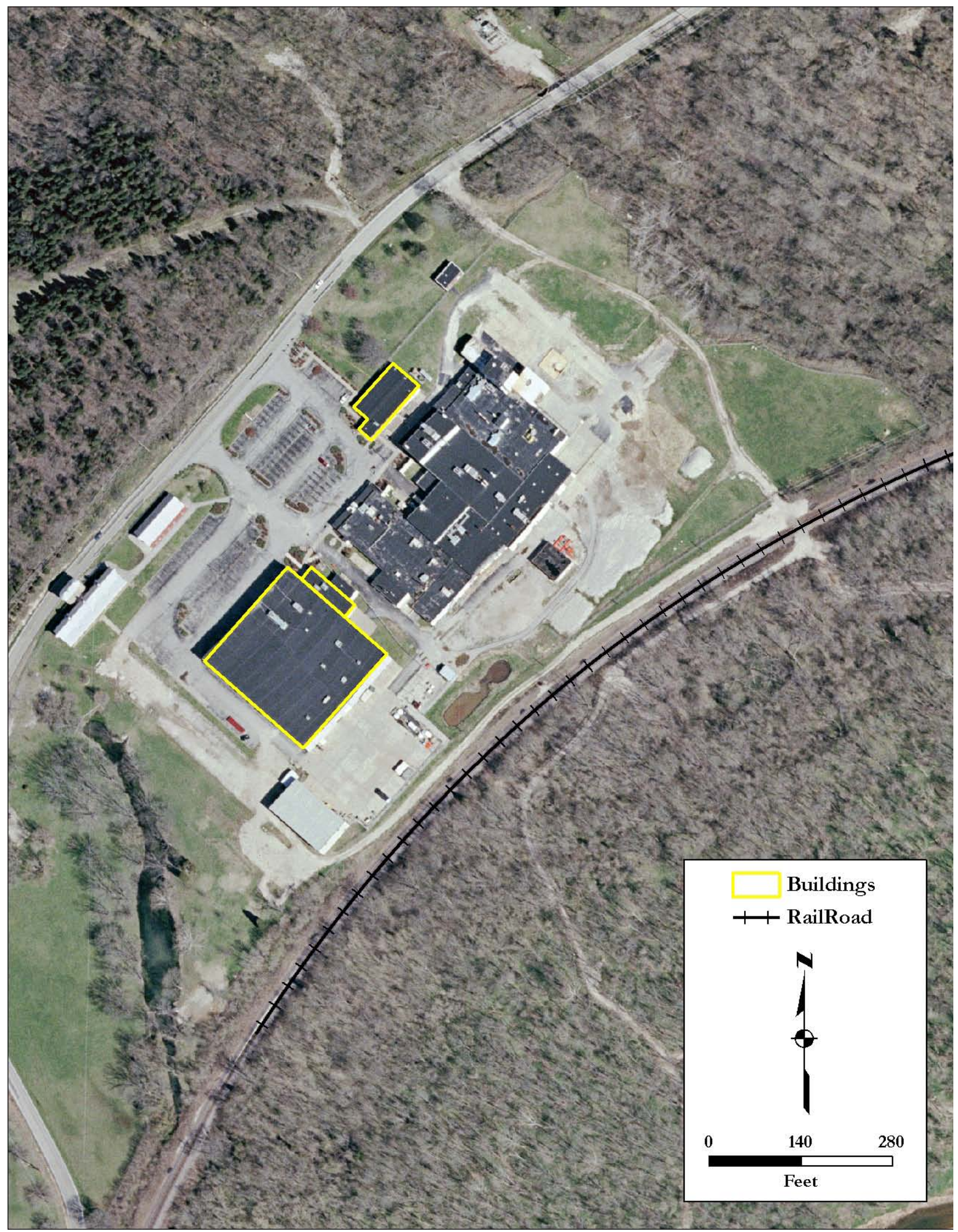

FIGURE 1: PLOT PLAN OF THE HEMATITE DECOMMISSIONING PROJECT BUILDINGS $230 \& 110$ HIGHLIGHTED 


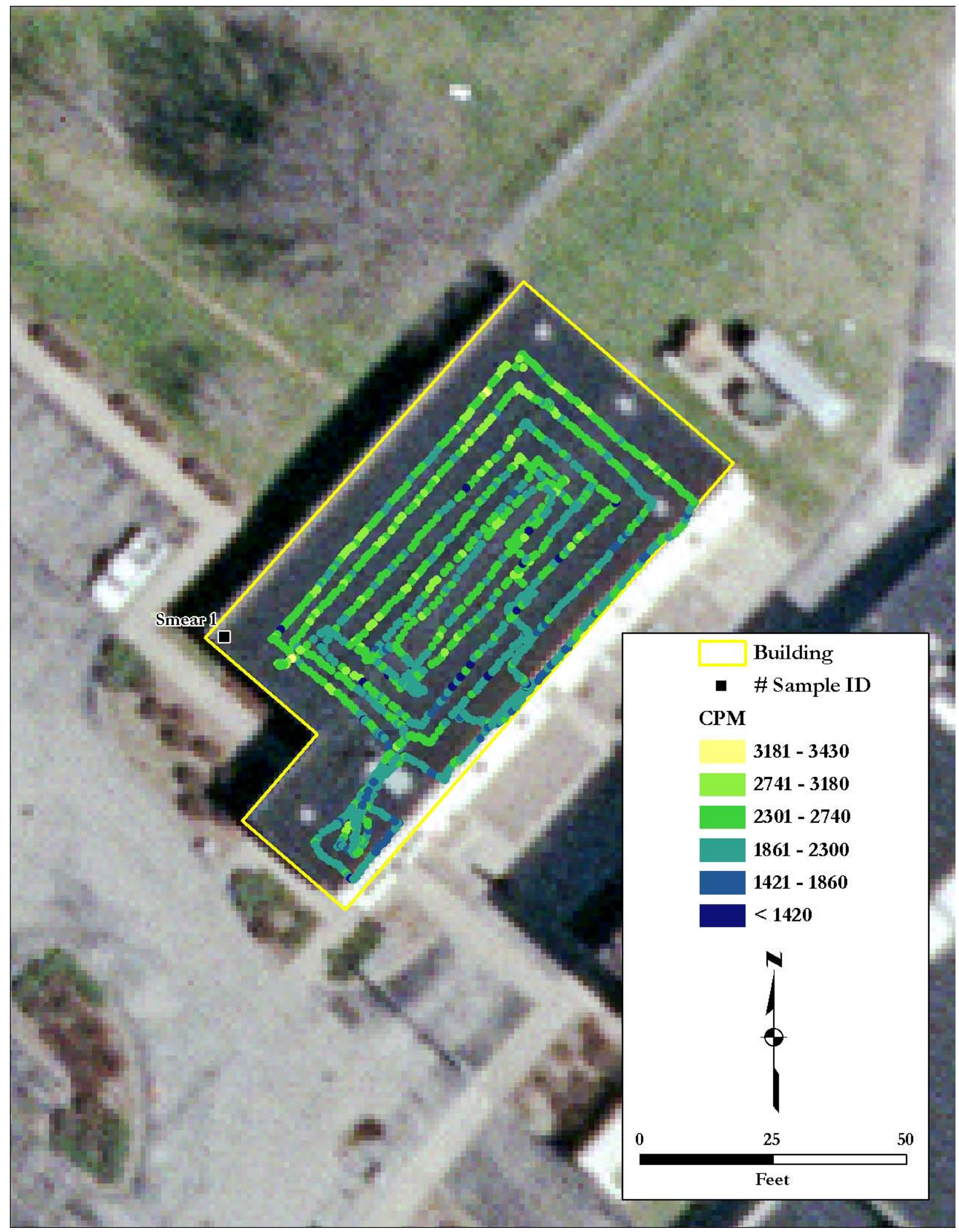

FIGURE 2: BUILDING 110 - GAMMA SCAN RESULTS AND SAMPLE LOCATION 


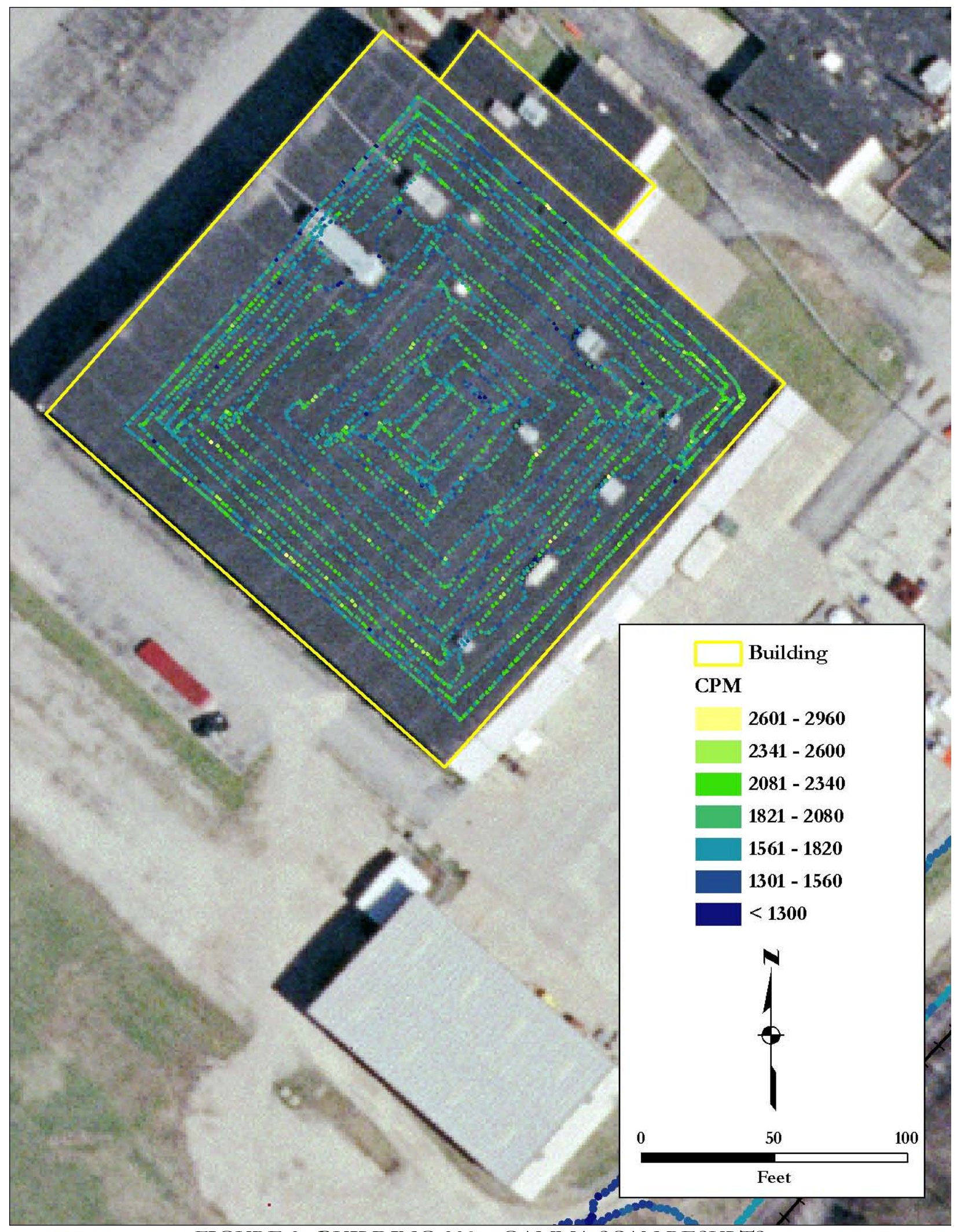

FIGURE 3: BUILDING 230 - GAMMA SCAN RESULTS 


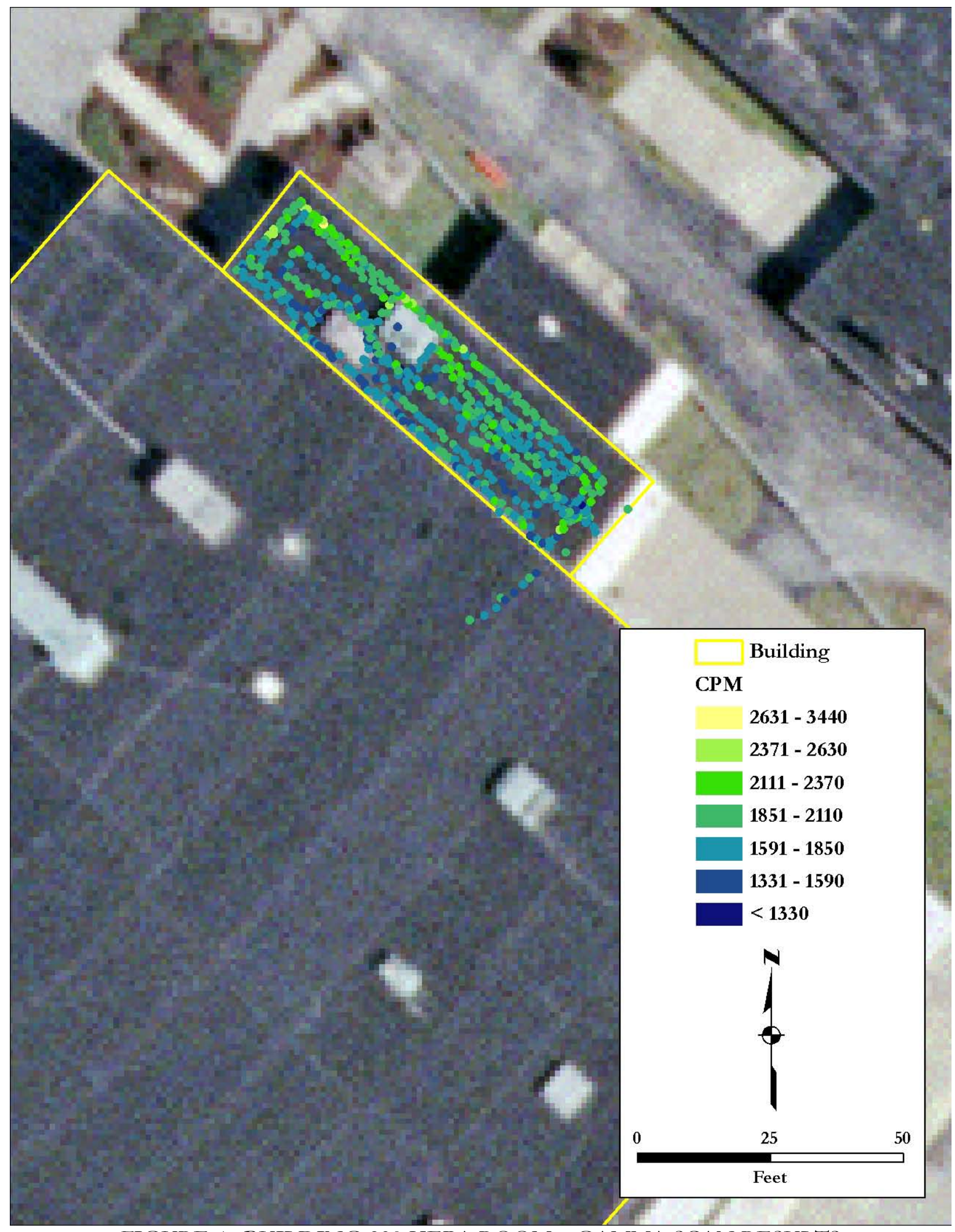

FIGURE 4: BUILDING 230 HEPA ROOM - GAMMA SCAN RESULTS 


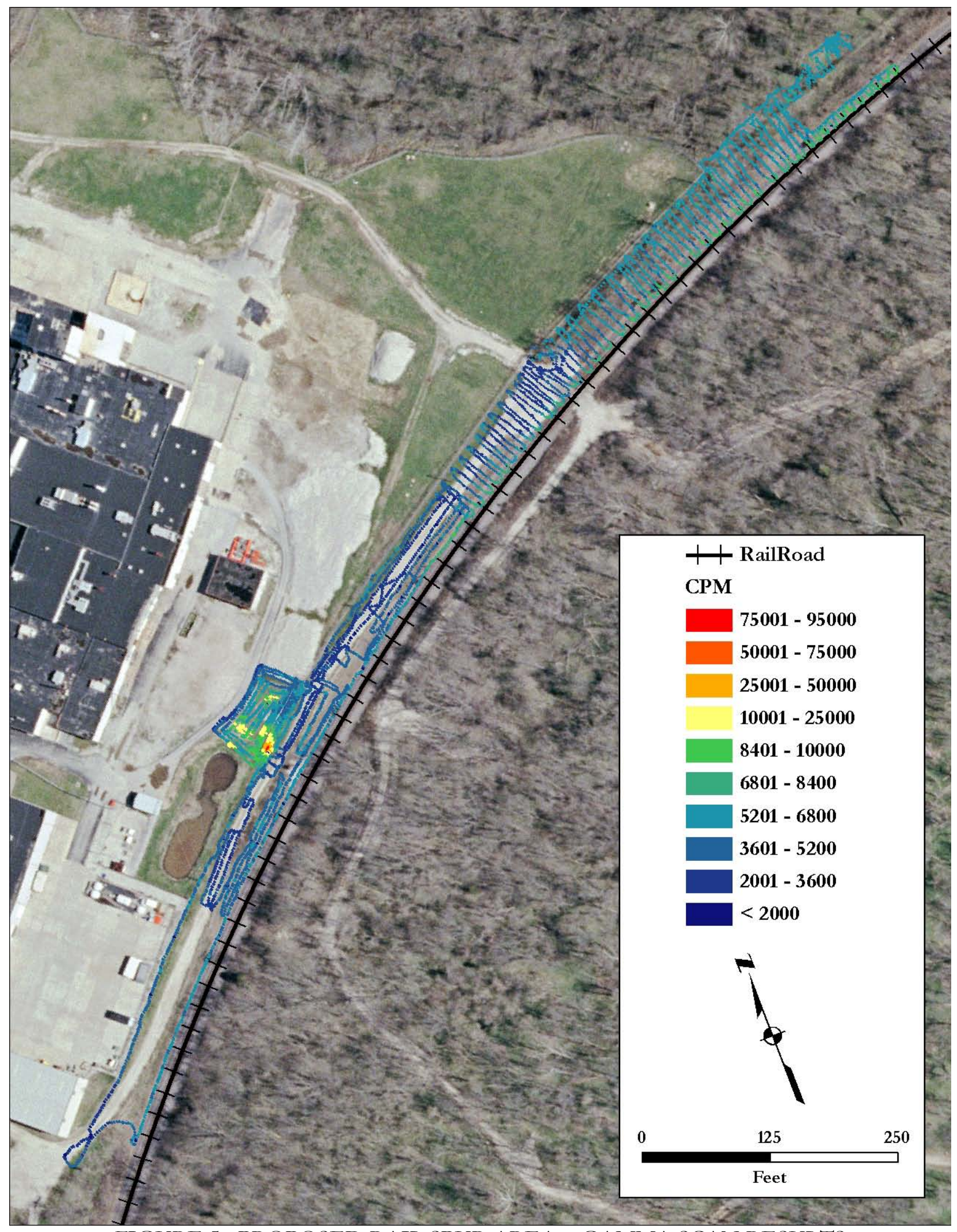

FIGURE 5: PROPOSED RAIL SPUR AREA - GAMMA SCAN RESULTS 


\section{APPENDIX B}

\section{TABLES}




\begin{tabular}{|c|c|c|c|c|c|}
\hline \multicolumn{6}{|c|}{$\begin{array}{c}\text { TABLE 1: CONCENTRATIONS AND COMPARISON OF RESULTS FOR } \\
\text { SELECTED GAMMA EMITTING RADIONUCLIDES IN SOIL SAMPLES } \\
\text { WESTINGHOUSE DECOMMISSIONING PROJECT } \\
\text { HEMATITE, MISSOURI }\end{array}$} \\
\hline \multicolumn{3}{|c|}{ Sample ID } & \multirow[b]{2}{*}{ Radionuclide $^{\mathrm{a}}$} & \multicolumn{2}{|c|}{ Radionuclide Concentrations $^{\mathrm{b}}(\mathrm{pCi} / \mathrm{g})$} \\
\hline ORISE & WEC & $\begin{array}{c}\text { NRC Region } \\
\text { III }\end{array}$ & & ORISE & WECc \\
\hline \multirow{6}{*}{$1768 S 0001$} & \multirow{6}{*}{ FS-19-1-SYS-12-SO-1 } & \multirow{6}{*}{ H-08-01 } & Th-228 & $0.98 \pm 0.09, \mathrm{~d} 0.07$ & $\mathrm{NR}^{\mathrm{e}}$ \\
\hline & & & Th-232 & $0.98 \pm 0.16,0.12$ & 0.9 \\
\hline & & & Total $\mathrm{Th}^{\mathrm{f}}$ & $1.96 \pm 0.18$ & NR \\
\hline & & & $\mathrm{U}-238$ & $8.14 \pm 0.82,0.91$ & 8.0 \\
\hline & & & $\mathrm{U}-235$ & $2.46 \pm 0.22,0.23$ & 2.1 \\
\hline & & & Total Us & $64.0 \pm 4.8$ & NR \\
\hline \multirow{6}{*}{$1768 S 0002$} & \multirow{6}{*}{ FS-19-1-SYS-12-SO-2 } & \multirow{6}{*}{$\mathrm{H}-08-02$} & Th-228 & $1.03 \pm 0.10,0.08$ & NR \\
\hline & & & Th-232 & $1.18 \pm 0.19,0.13$ & 1.2 \\
\hline & & & Total Th & $2.21 \pm 0.21$ & NR \\
\hline & & & $\mathrm{U}-238$ & $1.65 \pm 0.42,1.03$ & 2.3 \\
\hline & & & $\mathrm{U}-235$ & $0.22 \pm 0.09,0.23$ & 0.3 \\
\hline & & & Total U & $6.6 \pm 2.0$ & NR \\
\hline \multirow{6}{*}{$1768 S 0003$} & \multirow{6}{*}{ FS-19-1-SYS-12-SO-3 } & \multirow{6}{*}{ H-08-03 } & Th-228 & $1.11 \pm 0.10,0.06$ & NR \\
\hline & & & Th-232 & $1.18 \pm 0.18,0.13$ & 1.1 \\
\hline & & & Total Th & $2.29 \pm 0.21$ & NR \\
\hline & & & $\mathrm{U}-238$ & $1.59 \pm 0.40,0.72$ & 2.0 \\
\hline & & & $\mathrm{U}-235$ & $0.14 \pm 0.08,0.16$ & 0.1 \\
\hline & & & Total U & $4.8 \pm 1.8$ & NR \\
\hline \multirow{6}{*}{$1768 S 0004$} & \multirow{6}{*}{ FS-19-1-SYS-13-SO-1 } & \multirow{6}{*}{ H-08-04 } & Th-228 & $0.86 \pm 0.08,0.05$ & NR \\
\hline & & & Th-232 & $0.83 \pm 0.15,0.14$ & 0.7 \\
\hline & & & Total Th & $1.69 \pm 0.17$ & NR \\
\hline & & & U-238 & $6.57 \pm 0.69,0.92$ & 5.8 \\
\hline & & & U-235 & $1.73 \pm 0.17,0.20$ & 1.7 \\
\hline & & & Total U & $45.8 \pm 3.8$ & NR \\
\hline \multirow{6}{*}{$1768 S 0005$} & \multirow{6}{*}{ FS-19-1-SYS-16-SO-1 } & \multirow{6}{*}{ H-08-05 } & Th-228 & $0.60 \pm 0.06,0.06$ & NR \\
\hline & & & Th-232 & $0.62 \pm 0.12,0.12$ & 0.5 \\
\hline & & & Total Th & $1.22 \pm 0.13$ & NR \\
\hline & & & $\mathrm{U}-238$ & $19.4 \pm 1.5,1.0$ & 17.7 \\
\hline & & & U-235 & $6.10 \pm 0.43,0.25$ & 5.5 \\
\hline & & & Total U & $157.9 \pm 9.5$ & NR \\
\hline
\end{tabular}




\begin{tabular}{|c|c|c|c|c|c|}
\hline \multicolumn{6}{|c|}{$\begin{array}{c}\text { TABLE 1: CONCENTRATIONS AND COMPARISON OF RESULTS FOR } \\
\text { SELECTED GAMMA EMIT'TING RADIONUCLIDES IN SOIL SAMPLES } \\
\text { WESTINGHOUSE DECOMMISSIONING PROJECT } \\
\text { HEMATITE, MISSOURI }\end{array}$} \\
\hline \multicolumn{3}{|c|}{ Sample ID } & \multirow[b]{2}{*}{ Radionuclide $^{a}$} & \multicolumn{2}{|c|}{ Radionuclide Concentrations $^{\mathrm{b}}$ (pCi/g) } \\
\hline ORISE & WEC & $\begin{array}{c}\text { NRC Region } \\
\text { III }\end{array}$ & & ORISE & WECc \\
\hline \multirow{6}{*}{ 1768S0006 } & \multirow{6}{*}{ FS-19-1-SYS-16-SO-2 } & \multirow{6}{*}{ H-08-06 } & Th-228 & $1.01 \pm 0.09,0.07$ & NR \\
\hline & & & Th-232 & $1.04 \pm 0.17,0.14$ & 1.1 \\
\hline & & & Total Th & $2.05 \pm 0.19$ & NR \\
\hline & & & $\mathrm{U}-238$ & $3.52 \pm 0.54,1.02$ & 2.8 \\
\hline & & & $\mathrm{U}-235$ & $0.83 \pm 0.13,0.22$ & 0.7 \\
\hline & & & Total U & $22.4 \pm 2.9$ & NR \\
\hline \multirow{6}{*}{$1768 S 0007$} & \multirow{6}{*}{ FS-19-1-SYS-16-SO-3 } & \multirow{6}{*}{ H-08-07 } & Th-228 & $1.12 \pm 0.10,0.07$ & NR \\
\hline & & & Th-232 & $1.25 \pm 0.19,0.13$ & 1.1 \\
\hline & & & Total Th & $2.37 \pm 0.21$ & NR \\
\hline & & & $\mathrm{U}-238$ & $1.30 \pm 0.40,0.77$ & 0.8 \\
\hline & & & $\mathrm{U}-235$ & $0.11 \pm 0.08,0.19$ & 0.1 \\
\hline & & & Total U & $3.8 \pm 1.8$ & NR \\
\hline \multirow{6}{*}{$1768 S 0008$} & \multirow{6}{*}{ FS-19-1-SYS-19-SO-1 } & \multirow{6}{*}{ H-08-08 } & Th-228 & $0.33 \pm 0.04,0.03$ & NR \\
\hline & & & Th-232 & $0.31 \pm 0.07,0.07$ & 0.2 \\
\hline & & & Total Th & $0.64 \pm 0.08$ & NR \\
\hline & & & $\mathrm{U}-238$ & $2.21 \pm 0.34,0.54$ & 1.8 \\
\hline & & & $\mathrm{U}-235$ & $0.39 \pm 0.07,0.12$ & 0.5 \\
\hline & & & Total U & $11.1 \pm 1.6$ & NR \\
\hline \multirow{6}{*}{$1768 S 0009$} & \multirow{6}{*}{ FS-19-1-BIA-1-SO-1 } & \multirow{6}{*}{ H-08-09 } & Th-228 & $0.89 \pm 0.09,0.09$ & NR \\
\hline & & & Th-232 & $0.99 \pm 0.17,0.16$ & 1.0 \\
\hline & & & Total Th & $1.88 \pm 0.19$ & NR \\
\hline & & & $\mathrm{U}-238$ & $33.1 \pm 2.4,2.6$ & 28.7 \\
\hline & & & $\mathrm{U}-235$ & $8.57 \pm 0.57,0.38$ & 7.5 \\
\hline & & & Total U & $228 \pm 13$ & NR \\
\hline \multirow{6}{*}{$1768 S 0010$} & \multirow{6}{*}{ FS-19-1-BIA-2-SO-1 } & \multirow{6}{*}{ H-08-10 } & Th-228 & $0.87 \pm 0.08,0.07$ & NR \\
\hline & & & Th-232 & $0.90 \pm 0.16,0.13$ & 1.0 \\
\hline & & & Total Th & $1.77 \pm 0.18$ & NR \\
\hline & & & $\mathrm{U}-238$ & $21.6 \pm 1.7,1.5$ & 18.5 \\
\hline & & & $\mathrm{U}-235$ & $6.71 \pm 0.46,0.32$ & 5.8 \\
\hline & & & Total U & $170 \pm 10$ & NR \\
\hline \multirow{2}{*}{$1768 S 0011$} & \multirow{2}{*}{ FS-19-1-BIA-3-SO-1 } & \multirow{2}{*}{ H-08-11 } & Th-228 & $5.91 \pm 0.57,0.58$ & NR \\
\hline & & & Th-232 & $7.2 \pm 1.1,0.7$ & 5.6 \\
\hline
\end{tabular}




\begin{tabular}{|c|c|c|c|c|c|}
\hline \multicolumn{6}{|c|}{$\begin{array}{c}\text { TABLE 1: CONCENTRATIONS AND COMPARISON OF RESULTS FOR } \\
\text { SELECTED GAMMA EMIT'TING RADIONUCLIDES IN SOIL SAMPLES } \\
\text { WESTINGHOUSE DECOMMISSIONING PROJECT } \\
\text { HEMATITE, MISSOURI }\end{array}$} \\
\hline \multicolumn{3}{|c|}{ Sample ID } & \multirow[b]{2}{*}{ Radionuclide $^{a}$} & \multicolumn{2}{|c|}{ Radionuclide Concentrations $^{\mathrm{b}}$ (pCi/g) } \\
\hline ORISE & WEC & $\begin{array}{c}\text { NRC Region } \\
\text { III }\end{array}$ & & ORISE & WECc \\
\hline & & & Total Th & $13.1 \pm 1.2$ & NR \\
\hline & & & $\mathrm{U}-238$ & $838 \pm 54,20$ & 464.0 \\
\hline & & & $\mathrm{U}-235$ & $340 \pm 20,5$ & 213.0 \\
\hline & & & Total U & $8560 \pm 440$ & NR \\
\hline \multirow{6}{*}{$1768 S 0012$} & \multirow{6}{*}{ FS-19-1-BIA-3-SO-2 } & \multirow{6}{*}{ H-08-12 } & Th-228 & $1.12 \pm 0.09,0.05$ & NR \\
\hline & & & Th-232 & $1.14 \pm 0.17,0.10$ & 0.9 \\
\hline & & & Total Th & $2.26 \pm 0.19$ & NR \\
\hline & & & $\mathrm{U}-238$ & $5.17 \pm 0.57,0.85$ & 4.7 \\
\hline & & & $\mathrm{U}-235$ & $1.13 \pm 0.13,0.18$ & 1.0 \\
\hline & & & Total U & $30.8 \pm 2.9$ & NR \\
\hline \multirow{6}{*}{$1768 S 0013$} & \multirow{6}{*}{ FS-19-1-BIA-3-SO-3 } & \multirow{6}{*}{ H-08-13 } & Th-228 & $1.11 \pm 0.10,0.06$ & NR \\
\hline & & & Th-232 & $1.10 \pm 0.17,0.14$ & 1.3 \\
\hline & & & Total Th & $2.21 \pm 0.20$ & NR \\
\hline & & & $\mathrm{U}-238$ & $2.40 \pm 0.46,0.75$ & 2.7 \\
\hline & & & $\mathrm{U}-235$ & $0.45 \pm 0.11,0.20$ & 0.6 \\
\hline & & & Total U & $12.6 \pm 2.4$ & NR \\
\hline \multirow{6}{*}{$1768 S 0014$} & \multirow{6}{*}{ FS-19-1-BIA-4-SO-1 } & \multirow{6}{*}{ H-08-14 } & Th-228 & $0.41 \pm 0.05,0.04$ & NR \\
\hline & & & Th-232 & $0.48 \pm 0.09,0.09$ & 0.5 \\
\hline & & & Total Th & $0.89 \pm 0.10$ & NR \\
\hline & & & $\mathrm{U}-238$ & $34.3 \pm 2.4,1.1$ & 30.2 \\
\hline & & & $\mathrm{U}-235$ & $8.01 \pm 0.53,0.25$ & 7.1 \\
\hline & & & Total U & $216 \pm 12$ & NR \\
\hline \multirow{6}{*}{$1768 S 0015$} & \multirow{6}{*}{ FS-19-1-BIA-5-SO-1 } & \multirow{6}{*}{ H-08-15 } & Th-228 & $3.55 \pm 0.27,0.12$ & NR \\
\hline & & & Th-232 & $4.58 \pm 0.53,0.14$ & 3.9 \\
\hline & & & Total Th & $8.13 \pm 0.59$ & NR \\
\hline & & & $\mathrm{U}-238$ & $83.1 \pm 5.5,2.6$ & 66.0 \\
\hline & & & $\mathrm{U}-235$ & $31.8 \pm 1.8,0.6$ & 27.9 \\
\hline & & & Total U & $805 \pm 39$ & NR \\
\hline \multirow{4}{*}{ 1768S0016 } & \multirow{4}{*}{ FS-19-1-BIA-5-SO-2 } & \multirow{4}{*}{ H-08-16 } & Th-228 & $1.11 \pm 0.09,0.05$ & NR \\
\hline & & & Th-232 & $1.09 \pm 0.16,0.13$ & 1.2 \\
\hline & & & Total Th & $2.20 \pm 0.18$ & NR \\
\hline & & & $\mathrm{U}-238$ & $5.75 \pm 0.60,0.83$ & 4.6 \\
\hline
\end{tabular}




\begin{tabular}{|c|c|c|c|c|c|}
\hline \multicolumn{6}{|c|}{$\begin{array}{c}\text { TABLE 1: CONCENTRATIONS AND COMPARISON OF RESULTS FOR } \\
\text { SELECTED GAMMA EMIT'TING RADIONUCLIDES IN SOIL SAMPLES } \\
\text { WESTINGHOUSE DECOMMISSIONING PROJECT } \\
\text { HEMATITE, MISSOURI }\end{array}$} \\
\hline \multicolumn{3}{|c|}{ Sample ID } & \multirow[b]{2}{*}{ Radionuclide $^{a}$} & \multicolumn{2}{|c|}{ Radionuclide Concentrations $^{\mathrm{b}}$ (pCi/g) } \\
\hline \multirow[t]{3}{*}{ ORISE } & WEC & $\begin{array}{c}\text { NRC Region } \\
\text { III }\end{array}$ & & ORISE & WECc \\
\hline & & & $\mathrm{U}-235$ & $1.31 \pm 0.14,0.18$ & 1.2 \\
\hline & & & Total U & $35.5 \pm 3.1$ & NR \\
\hline \multirow{6}{*}{ 1768S0017 } & \multirow{6}{*}{ FS-19-1-BIA-5-SO-3 } & \multirow{6}{*}{ H-08-17 } & Th-228 & $1.08 \pm 0.10,0.06$ & NR \\
\hline & & & Th-232 & $0.97 \pm 0.16,0.14$ & 1.2 \\
\hline & & & Total Th & $2.05 \pm 0.19$ & NR \\
\hline & & & $\mathrm{U}-238$ & $1.33 \pm 0.38,0.71$ & 0.8 \\
\hline & & & $\mathrm{U}-235$ & $0.12 \pm 0.09,0.18$ & 0.1 \\
\hline & & & Total U & $4.1 \pm 2.0$ & NR \\
\hline \multirow{6}{*}{$1768 S 0018$} & \multirow{6}{*}{ FS-19-2-SYS-02-SO-2 } & \multirow{6}{*}{ H-08-18 } & Th-228 & $1.12 \pm 0.10,0.07$ & NR \\
\hline & & & Th-232 & $1.08 \pm 0.17,0.13$ & 1.3 \\
\hline & & & Total Th & $2.20 \pm 0.20$ & NR \\
\hline & & & $\mathrm{U}-238$ & $1.14 \pm 0.42,1.00$ & 1.0 \\
\hline & & & $\mathrm{U}-235$ & $0.31 \pm 0.26,0.31$ & 0.1 \\
\hline & & & Total U & $8.2 \pm 5.7$ & NR \\
\hline \multirow{6}{*}{ 1768S0019 } & \multirow{6}{*}{ FS-19-2-SYS-06-SO-3 } & \multirow{6}{*}{ H-08-19 } & Th-228 & $1.12 \pm 0.10,0.05$ & NR \\
\hline & & & Th-232 & $1.12 \pm 0.17,0.19$ & 1.0 \\
\hline & & & Total Th & $2.24 \pm 0.20$ & NR \\
\hline & & & $\mathrm{U}-238$ & $1.08 \pm 0.37,0.80$ & 1.7 \\
\hline & & & $\mathrm{U}-235$ & $-0.07 \pm 0.16,0.22$ & 0.1 \\
\hline & & & Total U & $-0.5 \pm 3.5$ & NR \\
\hline \multirow{6}{*}{$1768 \mathrm{~S} 0020$} & \multirow{6}{*}{ FS-19-2-SYS-10-SO-1 } & \multirow{6}{*}{ H-08-20 } & Th-228 & $0.96 \pm 0.09,0.05$ & NR \\
\hline & & & Th-232 & $0.75 \pm 0.14,0.16$ & 1.0 \\
\hline & & & Total Th & $1.71 \pm 0.17$ & NR \\
\hline & & & $\mathrm{U}-238$ & $1.35 \pm 0.84,1.03$ & 1.6 \\
\hline & & & $\mathrm{U}-235$ & $0.21 \pm 0.09,0.18$ & 0.1 \\
\hline & & & Total U & $6.1 \pm 2.1$ & NR \\
\hline \multirow{6}{*}{$1768 \mathrm{~S} 0021$} & \multirow{6}{*}{ FS-19-2-SYS-14-SO-1 } & \multirow{6}{*}{ H-08-21 } & Th-228 & $0.58 \pm 0.06,0.06$ & NR \\
\hline & & & Th-232 & $0.60 \pm 0.13,0.14$ & 0.7 \\
\hline & & & Total Th & $1.18 \pm 0.14$ & NR \\
\hline & & & $\mathrm{U}-238$ & $1.38 \pm 0.42,0.86$ & 1.4 \\
\hline & & & $\mathrm{U}-235$ & $0.09 \pm 0.12,0.21$ & 0.2 \\
\hline & & & Total U & $3.4 \pm 2.6$ & NR \\
\hline
\end{tabular}




\begin{tabular}{|c|c|c|c|c|c|}
\hline \multicolumn{6}{|c|}{$\begin{array}{c}\text { TABLE 1: CONCENTRATIONS AND COMPARISON OF RESULTS FOR } \\
\text { SELECTED GAMMA EMITTING RADIONUCLIDES IN SOIL SAMPLES } \\
\text { WESTINGHOUSE DECOMMISSIONING PROJECT } \\
\text { HEMATITE, MISSOURI }\end{array}$} \\
\hline \multicolumn{3}{|c|}{ Sample ID } & \multirow[b]{2}{*}{ Radionuclide $^{\mathrm{a}}$} & \multicolumn{2}{|c|}{ Radionuclide Concentrations ${ }^{\mathrm{b}}(\mathrm{pCi} / \mathrm{g})$} \\
\hline ORISE & WEC & $\begin{array}{c}\text { NRC Region } \\
\text { III }\end{array}$ & & ORISE & WEC \\
\hline \multirow{6}{*}{$1768 \mathrm{~S} 0022$} & \multirow{6}{*}{ FS-19-2-SYS-16-SO-1 } & \multirow{6}{*}{ H-08-22 } & Th-228 & $0.48 \pm 0.05,0.04$ & NR \\
\hline & & & Th-232 & $0.67 \pm 0.11,0.08$ & 0.4 \\
\hline & & & Total Th & $1.15 \pm 0.12$ & NR \\
\hline & & & $\mathrm{U}-238$ & $0.84 \pm 0.25,0.47$ & 0.8 \\
\hline & & & $\mathrm{U}-235$ & $0.15 \pm 0.36,0.13$ & 0.2 \\
\hline & & & Total U & $4.2 \pm 7.8$ & NR \\
\hline \multirow{6}{*}{$1768 S 0023$} & \multirow{6}{*}{ FS-19-2-SYS-16-SO-2 } & \multirow{6}{*}{ H-08-23 } & Th-228 & $0.95 \pm 0.08,0.06$ & NR \\
\hline & & & Th-232 & $1.02 \pm 0.16,0.11$ & 1.1 \\
\hline & & & Total Th & $1.97 \pm 0.18$ & NR \\
\hline & & & $\mathrm{U}-238$ & $1.64 \pm 0.40,0.83$ & 1.5 \\
\hline & & & U-235 & $0.05 \pm 0.25,0.27$ & 0.1 \\
\hline & & & Total U & $2.8 \pm 5.4$ & NR \\
\hline \multirow{6}{*}{$1768 S 0024$} & \multirow{6}{*}{ FS-19-2-SYS-16-SO-3 } & \multirow{6}{*}{ H-08-24 } & Th-228 & $1.17 \pm 0.10,0.05$ & NR \\
\hline & & & Th-232 & $1.09 \pm 0.17,0.13$ & 1.4 \\
\hline & & & Total Th & $2.26 \pm 0.20$ & NR \\
\hline & & & $\mathrm{U}-238$ & $1.03 \pm 0.37,0.82$ & 1.8 \\
\hline & & & $\mathrm{U}-235$ & $0.14 \pm 0.07,0.15$ & 0.1 \\
\hline & & & Total U & $4.2 \pm 1.6$ & NR \\
\hline \multirow{6}{*}{$1768 S 0025$} & \multirow{6}{*}{ FS-19-2-SYS-19-SO-1 } & \multirow{6}{*}{ H-08-25 } & Th-228 & $0.86 \pm 0.07,0.05$ & NR \\
\hline & & & Th-232 & $0.97 \pm 0.14,0.10$ & 0.8 \\
\hline & & & Total Th & $1.83 \pm 0.16$ & NR \\
\hline & & & $\mathrm{U}-238$ & $2.55 \pm 0.37,0.56$ & 1.6 \\
\hline & & & U-235 & $0.57 \pm 0.09,0.14$ & 0.5 \\
\hline & & & Total U & $15.5 \pm 2.0$ & NR \\
\hline
\end{tabular}




\begin{tabular}{|c|c|c|c|c|c|}
\hline \multicolumn{6}{|c|}{$\begin{array}{l}\text { TABLE 1: CONCENTRATIONS AND COMPARISON OF RESULTS FOR } \\
\text { SELECTED GAMMA EMITTING RADIONUCLIDES IN SOIL SAMPLES } \\
\text { WESTINGHOUSE DECOMMISSIONING PROJECT } \\
\text { HEMATITE, MISSOURI }\end{array}$} \\
\hline \multicolumn{3}{|c|}{ Sample ID } & \multirow{2}{*}{ Radionuclide $^{\mathrm{a}}$} & \multicolumn{2}{|c|}{ Radionuclide Concentrations $^{\mathrm{b}}(\mathrm{pCi} / \mathrm{g})$} \\
\hline ORISE & WEC & $\begin{array}{c}\text { NRC Region } \\
\text { III }\end{array}$ & & ORISE & WECc \\
\hline \multirow{6}{*}{$1768 S 0026$} & \multirow{6}{*}{ FS-19-2-SYS-21-SO-1 } & \multirow{6}{*}{ H-08-26 } & Th-228 & $0.92 \pm 0.09,0.08$ & NR \\
\hline & & & Th-232 & $1.00 \pm 0.18,0.17$ & 0.7 \\
\hline & & & Total Th & $1.92 \pm 0.20$ & NR \\
\hline & & & $\mathrm{U}-238$ & $2.2 \pm 3.2,0.9$ & 1.5 \\
\hline & & & U-235 & $0.36 \pm 0.10,0.16$ & 0.2 \\
\hline & & & Total U & $10.4 \pm 3.9$ & NR \\
\hline
\end{tabular}

${ }^{\mathrm{a}}$ For the ORISE analyses; Th-228 by Pb-212; Th-232 by Ac-228; U-238 by Th-234.

'The MDC's are after the comma.

${ }^{c}$ Radionuclide concentrations provided in a WEC report to the NRC (WEC 2008).

${ }^{\mathrm{d}}$ Uncertainties represent the $95 \%$ confidence level, based on total propagated uncertainties.

${ }^{\mathrm{e}}$ Not reported.

${ }^{\mathrm{f}}$ Total Th is the sum of concentrations of the Th-228 + Th-232.

${ }^{\mathrm{g}}$ The equation for Total U is U-238 + U-235 + $(21.7 * \mathrm{U}-235)$. 


\begin{tabular}{|c|c|c|c|c|c|c|}
\hline \multicolumn{7}{|c|}{$\begin{array}{c}\text { TABLE 2: CONCENTRATIONS OF URANIUM ISOTOPES } \\
\text { IN SOIL SAMPLES BY ALPHA SPECTROSCOPY AP11, } \\
\text { REVISION 4; INTERIM CP2, REVISION } 13 \\
\text { WESTINGHOUSE DECOMMISSIONING PROJECT } \\
\text { HEMATITE, MISSOURI }\end{array}$} \\
\hline \multicolumn{3}{|c|}{ Sample ID } & \multicolumn{4}{|c|}{ Radionuclide Concentrations (pCi/g) } \\
\hline \multirow{2}{*}{ ORISE } & \multirow{2}{*}{ WEC } & \multirow{2}{*}{$\begin{array}{c}\text { NRC } \\
\text { Region } \\
\text { III }\end{array}$} & \multirow{2}{*}{$\begin{array}{l}\text { WEC }^{\mathbf{a}} \\
\mathrm{U}-234\end{array}$} & \multicolumn{3}{|c|}{ ORISE } \\
\hline & & & & U-233/234 & U-235 & $\mathrm{U}-238$ \\
\hline $1768 S 0001$ & FS-19-1-SYS-12-SO-1 & H-08-01 & $\mathrm{NA}^{\mathrm{b}}$ & $53.2 \pm 3.9^{\mathrm{c}}, 0.0^{\mathrm{d}, \mathrm{e}}$ & $2.31 \pm 0.26,0.01$ & $7.27 \pm 0.61,0.03$ \\
\hline $1768 \mathrm{~S} 0002$ & FS-19-1-SYS-12-SO-2 & $\mathrm{H}-08-02$ & NA & $7.25 \pm 0.58,0.01$ & $0.35 \pm 0.06,0.01$ & $1.92 \pm 0.18,0.03$ \\
\hline $1768 \mathrm{~S} 0006$ & FS-19-1-SYS-16-SO-2 & $\mathrm{H}-08-06$ & NA & $22.5 \pm 2.4,0.1$ & $1.15 \pm 0.25,0.07$ & $3.55 \pm 0.50,0.06$ \\
\hline $1768 S 0007$ & FS-19-1-SYS-16-SO-3 & $\mathrm{H}-08-07$ & NA & $1.55 \pm 0.16,0.03$ & $0.07 \pm 0.03,0.01$ & $1.15 \pm 0.13,0.01$ \\
\hline $1768 S 0008$ & FS-19-1-SYS-19-SO-1 & $\mathrm{H}-08-08$ & 15.1 & $15.4 \pm 1.7,0.0$ & $0.81 \pm 0.19,0.03$ & $3.08 \pm 0.43,0.05$ \\
\hline 1768S0009 & FS-19-1-BIA-1-SO-1 & H-08-09 & 193 & $159 \pm 18,1$ & $6.4 \pm 2.2,0.5$ & $27.2 \pm 4.7,0.9$ \\
\hline $1768 S 0010$ & FS-19-1-BIA-2-SO-1 & H-08-10 & 67 & $148 \pm 15,0$ & $5.6 \pm 1.1,0.1$ & $21.8 \pm 2.8,0.2$ \\
\hline $1768 S 0011$ & FS-19-1-BIA-3-SO-1 & H-08-11 & 4070 & $8940 \pm 700,10$ & $340 \pm 60,7$ & $561 \pm 76,26$ \\
\hline $1768 \mathrm{~S} 0012$ & FS-19-1-BIA-3-SO-2 & $\mathrm{H}-08-12$ & 42.6 & $32.3 \pm 3.1,0$ & $1.3 \pm 0.28,0.04$ & $6.36 \pm 0.77,0.07$ \\
\hline $1768 S 0013$ & FS-19-1-BIA-3-SO-3 & $\mathrm{H}-08-13$ & 8.1 & $7.06 \pm 0.55,0.02$ & $0.28 \pm 0.05,0.01$ & $2.11 \pm 0.19,0.03$ \\
\hline $1768 S 0019$ & FS-19-2-SYS-06-SO-3 & H-08-19 & NA & $0.87 \pm 0.11,0.05$ & $0.05 \pm 0.03,0.04$ & $0.95 \pm 0.11,0.02$ \\
\hline $1768 S 0020$ & FS-19-2-SYS-10-SO-1 & H-08-20 & NA & $3.33 \pm 0.29,0.04$ & $0.13 \pm 0.04,0.03$ & $1.19 \pm 0.13,0.03$ \\
\hline $1768 S 0021$ & FS-19-2-SYS-14-SO-1 & $\mathrm{H}-08-21$ & NA & $3.09 \pm 0.29,0.04$ & $0.12 \pm 0.04,0.03$ & $1.16 \pm 0.14,0.03$ \\
\hline $1768 S 0022$ & FS-19-2-SYS-16-SO-1 & $\mathrm{H}-08-22$ & NA & $4.30 \pm 0.36,0.01$ & $0.17 \pm 0.04,0.01$ & $1.01 \pm 0.11,0.01$ \\
\hline $1768 \mathrm{~S} 0023$ & FS-19-2-SYS-16-SO-2 & H-08-23 & NA & $1.73 \pm 0.18,0.04$ & $0.08 \pm 0.03,0.05$ & $1.06 \pm 0.13,0.02$ \\
\hline $1768 \mathrm{~S} 0024$ & FS-19-2-SYS-16-SO-3 & $\mathrm{H}-08-24$ & NA & $1.14 \pm 0.13,0.02$ & $0.07 \pm 0.03,0.03$ & $1.07 \pm 0.13,0.01$ \\
\hline $1768 \mathrm{~S} 0025$ & FS-19-2-SYS-19-SO-1 & H-08-25 & NA & $11.8 \pm 1.0,0.1$ & $0.54 \pm 0.12,0.07$ & $2.27 \pm 0.27,0.08$ \\
\hline $1768 S 0026$ & FS-19-2-SYS-21-SO-1 & H-08-26 & 7.5 & $8.2 \pm 0.66,0.02$ & $0.51 \pm 0.08,0.01$ & $1.67 \pm 0.17,0.02$ \\
\hline
\end{tabular}

aRadionuclide concentrations provided in a WEC report to the NRC (WEC 2008).

${ }^{\mathrm{b}} \mathrm{NA}=$ Not analyzed by alpha spectroscopy.

cUncertainties represent the $95 \%$ confidence level, based on total propagated uncertainties.

dThe MDCs are after the comma..

eZero values are due to rounding. 


\begin{tabular}{|c|c|c|c|c|c|c|c|}
\hline \multicolumn{8}{|c|}{$\begin{array}{c}\text { TABLE 3: CONCENTRATIONS OF TECHNETIUM-99 } \\
\text { IN SOIL SAMPLES } \\
\text { BY LIQUID SCINTILLATION ANALYSIS } \\
\text { AP5, REVISION 17; CP4, REVISION } 3 \\
\text { WESTINGHOUSE DECOMMISSIONING PROJECT } \\
\text { HEMATITE, MISSOURI }\end{array}$} \\
\hline \multicolumn{3}{|c|}{ Sample ID } & \multicolumn{5}{|c|}{ Radionuclide Concentrations (pCi/g) } \\
\hline ORISE & WEC & NRC Region III ${ }^{a}$ & ORI & & & (wet) & $\mathbf{W E C}^{\mathbf{b}}$ \\
\hline $1768 S 0001$ & FS-19-1-SYS-12-SO-1 & $\mathrm{H}-08-01$ & 43.1 & \pm & $5.0^{c}$ & $\quad 0.3^{\mathrm{d}}$ & 27.0 \\
\hline $1768 \mathrm{~S} 0002$ & FS-19-1-SYS-12-SO-2 & $\mathrm{H}-08-02$ & 3.68 & \pm & 0.50 & $\quad 0.30$ & 3.0 \\
\hline $1768 \mathrm{~S} 0003$ & FS-19-1-SYS-12-SO-3 & H-08-03 & 1.68 & \pm & 0.26 &,$\quad 0.23$ & 49.5 \\
\hline $1768 S 0004$ & FS-19-1-SYS-13-SO-1 & H-08-04 & 68.8 & \pm & 8.0 &,$\quad 0.3$ & 32.8 \\
\hline $1768 \mathrm{~S} 0005$ & FS-19-1-SYS-16-SO-1 & H-08-05 & 41.3 & \pm & 4.8 &,$\quad 0.3$ & 21.2 \\
\hline $1768 \mathrm{~S} 0006$ & FS-19-1-SYS-16-SO-2 & H-08-06 & 3.31 & + & 0.44 & , $\quad 0.26$ & 3.8 \\
\hline $1768 S 0007$ & FS-19-1-SYS-16-SO-3 & H-08-07 & 1.13 & \pm & 0.23 &,$\quad 0.29$ & 0.4 \\
\hline $1768 S 0008$ & FS-19-1-SYS-19-SO-1 & H-08-08 & 22.3 & \pm & 2.6 & 0.3 & 13.1 \\
\hline $1768 S 0009$ & FS-19-1-BIA-1-SO-1 & H-08-09 & 60.1 & \pm & 7.0 & 0.3 & 34.6 \\
\hline $1768 \mathrm{~S} 0010$ & FS-19-1-BIA-2-SO-1 & H-08-10 & 39.9 & \pm & 3.4 &,$\quad 0.3$ & 11.5 \\
\hline $1768 \mathrm{~S} 0012$ & FS-19-1-BIA-3-SO-2 & H-08-12 & 3.98 & \pm & 0.41 &,$\quad 0.27$ & 0.9 \\
\hline $1768 \mathrm{~S} 0013$ & FS-19-1-BIA-3-SO-3 & $\mathrm{H}-08-13$ & 1.56 & - & 0.24 & $\quad 0.28$ & 0.5 \\
\hline $1768 \mathrm{~S} 0015$ & FS-19-1-BIA-5-SO-1 & H-08-15 & 141 & \pm & 12 &,$\quad 0^{\mathrm{e}}$ & 31.7 \\
\hline $1768 \mathrm{~S} 0016$ & FS-19-1-BIA-5-SO-2 & H-08-16 & 2.23 & 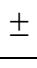 & 0.28 & , $\quad 0.27$ & 1.0 \\
\hline $1768 \mathrm{~S} 0017$ & FS-19-1-BIA-5-SO-3 & H-08-17 & 2.78 & - & 0.13 & , $\quad 0.24$ & 1.2 \\
\hline $1768 \mathrm{~S} 0018$ & FS-19-2-SYS-02-SO-2 & $\mathrm{H}-08-18$ & 0.21 & $\stackrel{1}{2}$ & 0.16 & $\quad 0.26$ & 0.1 \\
\hline $1768 \mathrm{~S} 0019$ & FS-19-2-SYS-06-SO-3 & H-08-19 & 0.29 & - & 0.16 & , $\quad 0.25$ & -0.6 \\
\hline $1768 \mathrm{~S} 0020$ & FS-19-2-SYS-10-SO-1 & $\mathrm{H}-08-20$ & 0.62 & \pm & 0.18 &,$\quad 0.26$ & 0.0 \\
\hline $1768 \mathrm{~S} 0022$ & FS-19-2-SYS-16-SO-1 & $\mathrm{H}-08-22$ & 7.05 & - & 0.86 & $\quad 0.24$ & 3.6 \\
\hline $1768 \mathrm{~S} 0023$ & FS-19-2-SYS-16-SO-2 & $\mathrm{H}-08-23$ & 0.90 & - & 0.20 &,$\quad 0.25$ & 0.5 \\
\hline $1768 \mathrm{~S} 0024$ & FS-19-2-SYS-16-SO-3 & $\mathrm{H}-08-24$ & 0.79 & $I$ & 0.20 & , $\quad 0.27$ & 0.6 \\
\hline $1768 \mathrm{~S} 0025$ & FS-19-2-SYS-19-SO-1 & H-08-25 & 22.7 & \pm & 2.7 &,$\quad 0.3$ & 10.4 \\
\hline $1768 S 0026$ & FS-19-2-SYS-21-SO-1 & H-08-26 & 14.8 & \pm & 1.7 &,$\quad 0.2$ & 12.9 \\
\hline
\end{tabular}

aThere was no wet portion available for ORISE for samples H-08-11, H-08-14, and H-08-21 for Tc-99 analysis.

bRadionuclide concentrations provided in a WEC report to the NRC (WEC 2008); WEC dried sample prior to analysis.

cUncertainties represent the $95 \%$ confidence level, based on total propagated uncertainties.

dThe MDCs are after the comma.

eZero value is due to rounding. 
APPENDIX C

MAJOR INSTRUMENTATION 


\section{APPENDIX C}

\section{MAJOR INSTRUMENTATION}

The display of a specific product is not to be construed as an endorsement of the product or its manufacturer by the author or her employer.

\section{SCANNING INSTRUMENT/DETECTOR COMBINATIONS}

\section{Alpha plus Beta}

Ludlum Floor Monitor Model 239-1

combined with

Ludlum Ratemeter-Scaler Model 2221

coupled to

Ludlum Gas Proportional Detector Model 43-37, Physical Area: $550 \mathrm{~cm}^{2}$

(Ludlum Measurements, Inc., Sweetwater, TX)

Ludlum Ratemeter-Scaler Model 2221

coupled to

Ludlum Gas Proportional Detector Model 43-68, Physical Area: $126 \mathrm{~cm}^{2}$

(Ludlum Measurements, Inc., Sweetwater, TX)

\section{$\underline{\text { Gamma }}$}

Ludlum Pulse Ratemeter Model 12

(Ludlum Measurements, Inc., Sweetwater, TX)

coupled to

Victoreen NaI Scintillation Detector Model 489-55, Crystal: $3.2 \mathrm{~cm}$ x $3.8 \mathrm{~cm}$

(Victoreen, Cleveland, $\mathrm{OH}$ )

\section{Direct MEASurement Instrument/Detector Combinations}

\section{Alpha plus Beta}

Ludlum Ratemeter-Scaler Model 2221

coupled to

Ludlum Gas Proportional Detector Model 43-68, Physical Area: $126 \mathrm{~cm}^{2}$

(Ludlum Measurements, Inc., Sweetwater, TX) 


\section{LABORATORY ANALYTICAL INSTRUMENTATION}

Low-Background Gas Proportional Counter

Model LB-5100-W

(Tennelec/Canberra, Meriden, CT)

High Purity Extended Range Intrinsic Detector

CANBERRA/Tennelec Model No: ERVDS30-25195

(Canberra, Meriden, CT)

Used in conjunction with:

Lead Shield Model G-11

(Nuclear Lead, Oak Ridge, TN) and

Multichannel Analyzer

Dell Workstation

(Canberra, Meriden, CT)

High Purity Extended Range Intrinsic Detector

Model No. GMX-45200-5

(AMETEK/ORTEC, Oak Ridge, TN)

used in conjunction with:

Lead Shield Model SPG-16-K8

(Nuclear Data)

Multichannel Analyzer

Dell Workstation

(Canberra, Meriden, CT)

High-Purity Germanium Detector

Model GMX-30-P4, 30\% Eff.

(AMETEK/ORTEC, Oak Ridge, TN)

Used in conjunction with:

Lead Shield Model G-16

(Gamma Products, Palos Hills, IL) and

Multichannel Analyzer

Dell Workstation

(Canberra, Meriden, CT)

Alpha Spectrometer

Model 7401 VR

(AMETEK/ORTEC, Oak Ridge, TN)

used in conjunction with

Dell Workstation

Canberra and Tennelec Alpha Spectrometers

(Canberra, Meriden, CT)

Tri-Carb Liquid Scintillation Analyzer

Model 3100

(Packard Instrument Co., Meriden, CT) 


\section{APPENDIX D}

\section{SURVEY AND ANALYTICAL PROCEDURES}




\section{APPENDIX D}

\section{SURVEY AND ANALYTICAL PROCEDURES}

\section{Project Health AND SAFETy}

The proposed survey and sampling procedures were evaluated to ensure that any hazards inherent to the procedures themselves were addressed in current job hazard analyses. Prior to onsite activities, a pre-job integrated safety management checklist was completed and discussed with field personnel.

Additionally, upon arrival on site, a walk-down of the site was performed to identify hazards present. All survey and laboratory activities were conducted in accordance with ORISE health and safety and radiation protection procedures (April 2008 and September 2005).

\section{QuAlity Assurance}

Analytical and field survey activities were conducted in accordance with procedures from the following documents:

- Survey Procedures Manual (May 1, 2008)

- Laboratory Procedures Manual (September 10, 2008)

- Quality Program Manual (November 1, 2007)

The procedures contained in these manuals were developed to meet the requirements of Department of Energy Order 414.1C and the U.S. Nuclear Regulatory Commission Quality Assurance Manual for the Office of Nuclear Material Safety and Safeguards and contain measures to assess processes during their performance.

Calibration of all field and laboratory instrumentation was based on standards/sources, traceable to NIST. Quality control procedures include:

- Daily instrument background and check-source measurements to confirm that equipment operation is within acceptable statistical fluctuations.

- Participation in MAPEP, NRIP, and ITP Laboratory Quality Assurance Programs.

- Training and certification of all individuals performing procedures.

- Periodic internal and external audits. 


\section{Calibration Procedures}

Detectors used for assessing surface activity were calibrated in accordance with ISO-7503 ${ }^{1}$ recommendations. Total alpha plus beta efficiencies $\left(\varepsilon_{\text {total }}\right)$ were determined for each instrument/detector combination and consisted of the product of the $2 \pi$ instrument efficiency $\left(\varepsilon_{i}\right)$ and surface efficiency $\left(\varepsilon_{\mathrm{s}}\right): \varepsilon_{\mathrm{total}}=\varepsilon_{\mathrm{i}} \times \varepsilon_{\mathrm{s}}$.

Tc-99 was selected as the beta calibration source. The $2 \pi$ beta instrument efficiency $\left(\varepsilon_{\mathrm{i}}\right)$ factor for the gas proportional detector used to collect direct measurements was 0.40. ISO-7503 recommends an $\varepsilon_{\mathrm{s}}$ of 0.25 for Tc-99. The total beta efficiency was 0.10 .

\section{SURVEY PROCEDURES}

\section{$\underline{\text { Surface Scans }}$}

Structural surface scans were performed by passing the detectors slowly over the surface while the distance between the detector and the surface was maintained at a minimum. A large surface area $\left(550 \mathrm{~cm}^{2}\right)$ gas proportional floor monitor with a $0.8 \mathrm{mg} / \mathrm{cm}^{2}$ window was used to scan the building roofs. A NaI scintillation detector was also used. Vents/HEPA surfaces were scanned using small area $\left(126 \mathrm{~cm}^{2}\right)$ hand-held detectors with a $0.8 \mathrm{mg} / \mathrm{cm}^{2}$ window. Identification of elevated radiation levels were based on increases in the audible signal from the recording and/or indicating instrument.

Beta surface scan minimum detectable concentrations (MDCs) were estimated using the calculational approach described in NUREG-1507. ${ }^{2}$ The scan MDC is a function of many variables, including the background level. Additional parameters selected for the calculation of scan MDCs included a two-second observation interval, a specified level of performance at the first scanning stage of $95 \%$ true positive rate and $25 \%$ false positive rate, which yields a $d$ 'value of 2.32 (NUREG-1507, Table 6.1), and a surveyor efficiency of 0.5. The beta total efficiency was 0.10 .

To illustrate an example for a hand-held gas proportional detector using the instrument background of $372 \mathrm{cpm}$, the minimum detectable count rate (MDCR) and scan MDC can be calculated as follows:

\footnotetext{
${ }^{1}$ International Standard. ISO 7503-1, Evaluation of Surface Contamination - Part 1: Beta-emitters (maximum beta energy greater than 0.15 MeV) and alpha-emitters. August 1, 1988 .

${ }^{2}$ NUREG-1507. Minimum Detectable Concentrations with Typical Radiation Survey Instruments for Various Contaminants and Field Conditions. US Nuclear Regulatory Commission. Washington, DC; June 1998.
} 


$$
\begin{aligned}
& \mathrm{b}_{\mathrm{i}}=(372 \mathrm{cpm})(2 \mathrm{~s})(1 \mathrm{~min} / 60 \mathrm{~s})=12.4 \text { counts } \\
& \operatorname{MDCR}=(2.32)(12.4 \mathrm{counts})^{1 / 2}[(60 \mathrm{~s} / \mathrm{min}) /(2 \mathrm{~s})]=245 \mathrm{cpm} \\
& \operatorname{MDCR}_{\text {surveyor }}=245 /(0.5)^{1 / 2}=347 \mathrm{cpm}
\end{aligned}
$$

The scan MDC is calculated using the beta total efficiency of 0.10 .

$$
\text { ScanMDC }=\frac{M D C R_{\text {surveyor }}}{\left(\varepsilon_{s}\right)\left(\varepsilon_{i}\right)} \mathrm{dpm} / 100 \mathrm{~cm}^{2}
$$

For the given background, the estimated scan MDC was 3,466 dpm/100 $\mathrm{cm}^{2}$ for the hand-held gas proportional detector.

The identification of elevated radiation levels that could exceed the site criteria were determined based on an increase in the audible signal from the indicating instrument.

Specific scan MDCs for the NaI scintillation detector were not determined as the instrument was used solely as a qualitative means to identify elevated gamma radiation levels in excess of background.

\section{Surface Activity Measurements}

Measurements of total beta surface activity levels were performed using hand-held gas proportional detectors coupled to portable ratemeter-scalers. Count rates (cpm), which were integrated over one minute with the detector held in a static position, were converted to activity levels $\left(\mathrm{dpm} / 100 \mathrm{~cm}^{2}\right)$ by dividing the count rate by the total static efficiency $\left(\varepsilon_{\mathrm{i}} \times \varepsilon_{\mathrm{s}}\right)$ and correcting for the physical area of the detector. ORISE did not determine construction material-specific background for each surface type encountered for determining net count rates. Instead, ORISE took a conservative approach and did not subtract material specific backgrounds in determining surface activity levels since the site specific DCGLs have not been approved. 
The a priori $\mathrm{MDC}$ for surface activity measurements was calculated using the following equation:

$$
M D C=\frac{3+(4.65 \sqrt{B)}}{T x \varepsilon_{\text {Total }} x G}
$$

Where:

$$
\begin{array}{lll}
\mathrm{B} & = & \text { background (total counts) in time interval, } \mathrm{T} \\
\mathrm{T} & = & \text { count time (min) used for field instruments } \\
\varepsilon_{\mathrm{Total}} & = & \text { total efficiency }=\varepsilon_{\mathrm{i}} \times \varepsilon_{\mathrm{s}} \\
\varepsilon_{\mathrm{i}} & = & \text { instrument efficiency } \\
\varepsilon_{\mathrm{s}} & = & \text { source efficiency } \\
\mathrm{G} & = & \text { geometry (physical detector area } \left.\mathrm{cm}^{2} / 100\right)
\end{array}
$$

The a priori beta static MDC was approximately $736 \mathrm{dpm} / 100 \mathrm{~cm}^{2}$ using the total efficiency of 0.10 instrument background of $372 \mathrm{cpm}$. The physical surface area assessed by the gas proportional detector used was $126 \mathrm{~cm}^{2}$.

\section{$\underline{\text { Removable Activity Measurements }}$}

Removable gross alpha and gross beta activity levels were determined using numbered filter paper disks, $47 \mathrm{~mm}$ in diameter. Moderate pressure was applied to the smear and approximately $100 \mathrm{~cm}^{2}$ of the surface was wiped. Smears were placed in labeled envelopes with the location and other pertinent information recorded.

\section{RADiOlogicAl ANALYSIS}

\section{Gross Alpha/Beta}

Smears were counted on a low-background gas proportional system for gross alpha and beta activity. The MDCs of the procedure were $9 \mathrm{dpm} / 100 \mathrm{~cm}^{2}$ and $15 \mathrm{dpm} / 100 \mathrm{~cm}^{2}$ for a 2 -minute count time for gross alpha and gross beta, respectively.

\section{Alpha Spectroscopy}

Solid samples were crushed and homogenized. Soil samples were dissolved by potassium fluoride and pyrosulfate fusion and the elements of interest were precipitated with barium sulfate. Barium sulfate precipitate was redissolved and the specific element of interest-isotopic uranium was 
individually separated by extraction chromatography using Eichrom resins and re-precipitated with a cerium fluoride carrier. The precipitate was then analyzed using ion implanted detectors (Canberra), alpha spectrometers (Tennelec and Canberra), and a multichannel analyzer (Nuclear Data). The typical MDC of the procedure for a 1000 minute count time is $0.02 \mathrm{pCi} / \mathrm{g}$ for solids.

\section{Tc-99}

Solid samples are leached with dilute nitric acid. The leachates are passed through an extraction chromatogaphic column containing a resin (TEVA resin) which is highly specific for technetium in pertechnatate form. The technetium is absorbed onto the extraction resin. The resin is added to a scintillation vial containing an appropriate cocktail and counted for 60 minutes using a liquid scintillation analyzer. All interfering beta emitting radionuclides are effectively removed (including C-14, P-32, S-35, Sr-90, Y-90, and Th234) using TEVA resin under the conditions in this procedure. Tritium may follow technetium due to the absorption of some tritium-labeled compounds by the resin. Possible tritium interferences are eliminated by setting the technetium counting window above the maximum energy for tritium beta particles. The typical MDC of the procedure is $2 \mathrm{pCi} / \mathrm{g}$ for a one gram aliquot.

\section{DETECTION LIMITS}

Detection limits, referred to as MDC, were based on 3 plus 4.65 times the standard deviation of the background count $\left[3+\left(4.65(\mathrm{BKG})^{1 / 2}\right)\right]$. Because of variations in background levels, measurement efficiencies, and contributions from other radionuclides in samples, the detection limits differ from sample to sample and instrument to instrument. 